\title{
SCAPHOSEPALUM MANNINGII LUER (ORCHIDACEAE: PLEUROTHALLIDINAE), A NEW SPECIES FOR COSTA RICA
}

\author{
STIG DALSTRÖM \\ Marie Selby Botanical Gardens, 811 South Palm Avenue, Sarasota, FL 34236, U.S.A. \\ Jardín Botánico Lankester, Universidad de Costa Rica
}

\begin{abstract}
A species previously known from a single collection in Venezuela; Scaphosepalum manningii was recently discovered in the Boracayan forest reserve in southwestern Costa Rica. It is here illustrated and compared with a closely related and, for Costa Rica, possibly sympatric species; Scaphosepalum clavellatum.
\end{abstract}

RESUMEN. Scaphosepalum manningii, previamente conocida solo por una única recolecta de Venezuela, fue recién descubierta en la reserva forestal Boracayan, en el suroeste de Costa Rica. La especie es ilustrada y comparada con Scaphosepalum clavellatum, una especie estrechamente relacionada y talvéz simpátrica.

Key words / Palabras Clave: Orchidaceae, Pleurothallidiinae, Scaphosepalum, Scaphosepalum manningii, Scaphosepalum clavellatum, Costa Rica

Orchid taxonomy is a science filled with surprises and unexpected discoveries. Part of the reason for this is that we sometimes tend to have preconceived ideas about specific concepts, natural variation and distribution patterns. Sometimes the word "endemic" is used prematurely when in fact we only know too little, and sometimes we use separate geographical distributions of populations to justify separate species distinctions simply because we have not yet been able to find plants in the intermediate area.

During a preliminary plant inventory of the Boracayan wildlife refuge in Costa Rica, owned and managed by Ann Patton and John Bender, in MayJune of 2003, an inconspicuous non-flowering member of Pleurothallidinae was collected by staff from the Marie Selby Botanical Gardens, Sarasota, Florida, in cooperation with staff from Lankester Botanical Garden, University of Costa Rica (border between San José and Puntarenas: Fila Costeña, ca. $10 \mathrm{~km}$ E of Dominical, Southern Fila Tinamastes near Cuesta Yeguas, Refugio de Vida Silvestre Boracayán, $9^{\circ} 14.9^{\prime} \mathrm{N} 83^{\circ} 45.2^{\prime} \mathrm{W}, 800-1000 \mathrm{~m}$, epiphyte on fallen branch along road cut, 26 May 2003, J.R. Clark et al. 103a, SEL 2003-0256A). Approximately six months later the plant began to flower in cultivation in the U.S., and surprisingly it was a species previously known only from a single collection in Venezuela [Aragua: near Colonia Tovar, collected by S. Manning and Carlos García, 1995, flowering in cultivation at Estover, Tarporley, England, 19 July 1997, S. Manning 95-0723 (MO)]. This species was described by C.A. Luer in 1998 as Scaphosepalum manningii (Luer 1998).

The flower of the Costa Rican plant is attractively dark yellow with purple stripes and with a clear and dark purple dorsal sepal. Scaphosepalum manningii (Fig. 1, 2 A-B) is compared with the closely related Central American species S. clavellatum (Fig. 2 CD), the former distinguisehd by the well-developed cushions on the lateral sepals. Scaphosepalum clavellatum is also a widely distributed species, ranging from Costa Rica through Panama into western Ecuador. No collections are cited from Colombia, but the range clearly indicates that it can be found there as well. The major difference between the two species is the shape and size of the cushions on the lateral sepals, large and well developed in $S$. manningii and significantly less so in $S$. clavellatum. The specific importance of these cushions is currently unknown, but successful pollination studies by several talented orchid students, such as Lorena Endara from Ecuador and Mario Blanco from Costa Rica, may well contribute to solve these mysteries in the near future. 

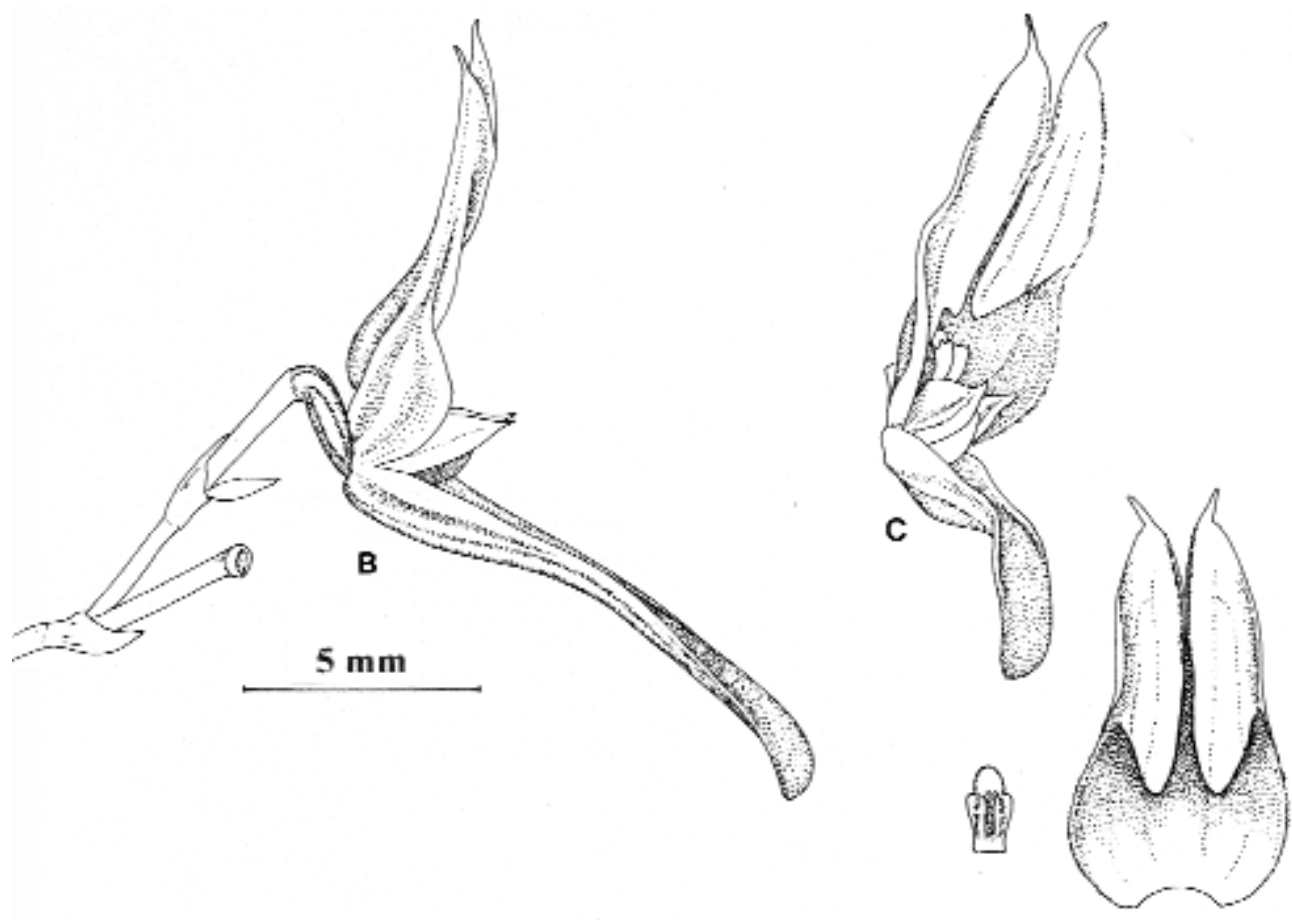

D
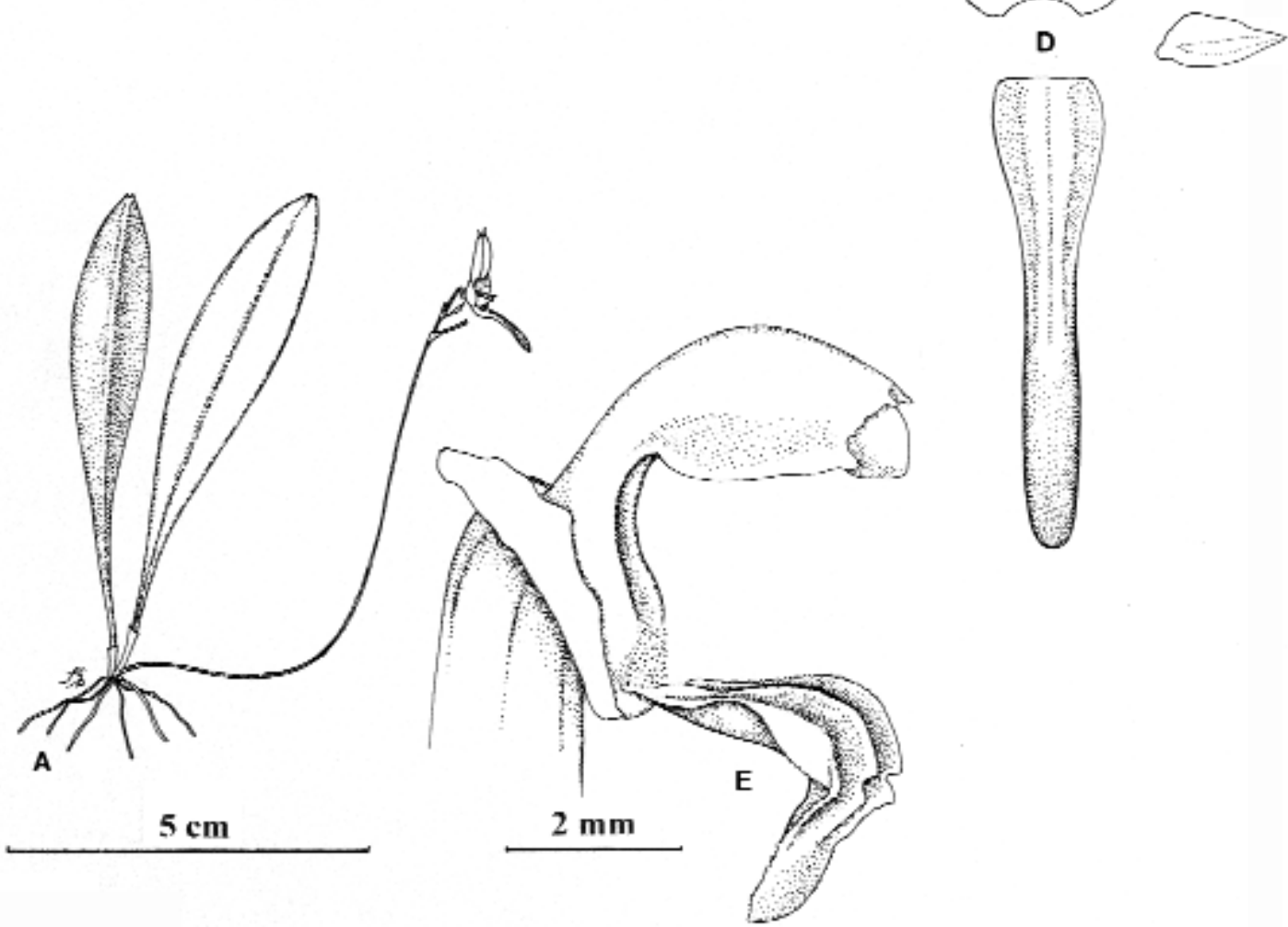

Figure 1. Scaphosepalum manningii Luer. A - Plant habit. B - Flower, lateral view. C - Flower, front view. D Floral diagram. E - Column and lip, lateral view. VOUCHER: SEL 2003-0256A. 

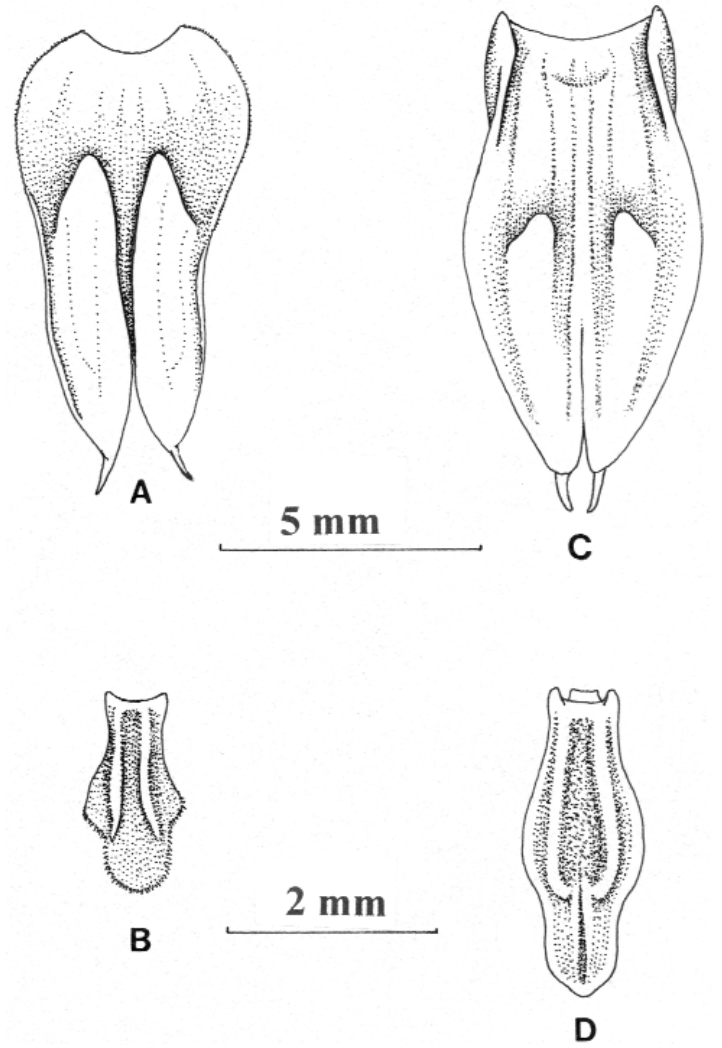

Figure 2. Scaphosepalum manningii. A - Lateral sepals. B - Lip, dorsal view. VoucHER: SEL 2003-0256A. Scaphosepalum clavellatum. C - Lateral sepals. D - Lip, dorsal view. Voucher: C. Luer et al. 748 (SEL).
During a second visit to Boracayan in January of 2004 the author found additional plants of S. manningii in flower. The color of the flowers in the second population was less attractively pale yellow. In May of 2004, a plant from the original expedition flowered in cultivation at Lankester Garden [border between San José and Puntarenas: Fila Costeña, ca. $10 \mathrm{~km}$ E of Dominical, Refugio de Vida Silvestre Boracayán, vicinity of the Catarata del San Luis along the southern Fila Tinamastes in the upper, northern Río Higuerón basin, steep rocky slope with humid, mossy forest at base of bluff by the waterfall, $9^{\circ} 15.01^{\prime} \mathrm{N} 83^{\circ} 44.8^{\prime} \mathrm{W}, 700-800 \mathrm{~m}, 27$ May 2003, flowered in cultivation at Jardín Botánico Lankester, 26 May 2004, J.R. Clark et al. 222 (USJ-Spirit)].

Acknowlegments.I thank Ann Patton and John Bender for their great generosity and support and Franco Pupulin for his comments and suggestions.

\section{Literature Cited}

Luer, C.A. 1988. Addenda to Lepanthes, Masdevallia, Platystele, Pleurothallis, Restrepia and Scaphosepalum. Monogr. Syst. Bot. Missouri Bot. Gard. 65: 101-122. 